\title{
Austerity in the euro area: the sad state of economic policy in Germany and the EU
}

\author{
Achim Truger \\ Department of Business and Economics, Berlin School of Economics and Law, Germany
}

The euro area is currently going through its worst period of recession and economic stagnation since the Great Depression and World War II. The article tries to give an impression of the extraordinary degree of fiscal austerity and the devastating economic effects it has already had and must be expected to have in the near future. In addition it is argued that both the lack of economic justification and the devastating consequences of the fiscal policies currently executed should have been absolutely obvious even from a mainstream perspective. Therefore the sad state of economic policies in the euro area is that it did not even follow moderate mainstream proposals but instead seemed to rely on radical and outdated theoretical or purely ideological foundations. Germany as the most economically and politically influential member state of the euro area seems to be most infected with such radical ideas.

Keywords: fiscal policy, Hamburg appeal, austerity, debt brake, fiscal compact, Germany, euro area

JEL codes: E61, E62, E64, E65, H62, H63

\section{INTRODUCTION}

The title of the present article is almost self-explanatory. For anybody who has taken a look at recent data it is obvious that, since the outbreak of the euro crisis, austerity with severe cuts in government spending and some tax hikes is ruling fiscal policy in many European countries and especially in the European periphery. And, of course, the sad state of economic policy is also quite obvious. After a weak recovery following the severe recession in the wake of the global financial and economic crisis in 2009, the euro area economy fell back to recession in 2012 and will probably not recover during 2013. Most probably, even by 2014, 6 years after the beginning of the recession, real GDP will not have reached its pre-crisis level - a period of severe economic stagnation unprecedented since the Great Depression and World War II. Consequently, unemployment rates are soaring. During 2013 they are expected to reach record levels of more than 12 per cent in the euro area with even more intolerable levels in the periphery around 27 per cent in both Greece and Spain according to the EU Commission's Winter forecast (European Commission 2013). In this situation, Central Bank interest rates are close to their lower bound and therefore interest rate policy is powerless at a time when unit labour cost growth is weak and even deflationary in most economies of the periphery. Fiscal policy as the only instrument left for stabilisation is prevented from playing its proper role and even forced to further aggravate the crisis by the tightened Stability and Growth Pact (SGP) and by its further tightening in the Fiscal Compact (FC).

It is therefore one purpose of the present article to give an impression of the extraordinary degree of fiscal austerity and the devastating economic effects it has already 
had and must be expected to have in the near future. But this description covers only the most obvious aspect of the sad state of economic policy in the euro area. What is even worse is that both the lack of economic justification and the devastating consequences of the fiscal policies currently executed should have been absolutely obvious even from a mainstream perspective. This article therefore argues that the reason for the sad state of economic policies in the euro area is that it does not even follow moderate mainstream proposals but instead seems to rely on radical and outdated theoretical or purely ideological foundations. Germany, as the most economically and politically influential member state of the euro area, seems to be most infected with such radical ideas.

Section 2 will therefore deal with the economic policy debate in Germany and will focus on the so-called 'Hamburg appeal' of 250 German economics professors as a stunning example of stubborn anti-Keynesianism that denied any usefulness of expansionary fiscal policy in opposition both to textbook knowledge and specific empirical evidence in the face of a prolonged demand-side crisis in Germany in 2005. Section 3 deals with the German debt brake which was introduced into the German constitution in 2009, partly as a consequence of the intellectual climate described. It will be shown that the debt brake which became a role model for the Fiscal Compact on the European level lacks economic justification and that the German success in terms of fiscal consolidation cannot be traced back to this instrument but that it is mostly due to good luck gleaned from the unexpectedly strong recovery. Section 4 will then turn to austerity in the euro area and try to give an assessment of the order of magnitude of the fiscal consolidation efforts that have already been implemented and that must be expected for the future. Section 5 discusses the probable economic effects of austerity by focusing on the question of the size of the multiplier. Section 6 sums up and briefly draws some economic policy conclusions.

\section{THE 'HAMBURG APPEAL' AND THE FAILURE OF THE GERMAN ECONOMICS PROFESSION AS AN INTELLECTUAL BACKGROUND FOR HARD-NOSED AUSTERITY POLICIES}

When the euro crisis escalated in 2010, Wolfgang Münchau wrote in the Financial Times (17 November 2010) that the degree of incompetence at the top level of the German government was breathtaking. In fact, German officials acted as if they deliberately wanted to worsen the crisis with their reluctance and their insistence on so-called sound economic principles when it should have been clear that sticking to those principles would cause economic disaster. Later on, two leading German central bankers, Axel Weber, the president of the Bundesbank, and Jürgen Stark, the chief economist of the ECB, resigned from their posts, because they were against the ECB's buying of government bonds in the secondary market of countries currently in trouble. Of course, one should not assume evil intentions by German politicians. It is instead highly probable that they believe in what they are doing. One of the potential reasons for those beliefs is that the vast majority of the German economics profession supplies them with and supports them in their views.

The obviously rather special attitudes and ideas dominating the German discussion when it comes to macroeconomic policies had been noticed long before the current crisis. Back in 1999, Paul Krugman wrote about the problems to be expected in the newly created euro area in one of his op-eds in the New York Times entitled 
'Why Germany kant kompete'. He argued that the main difference between Germany and the US may not be political but philosophical:

The real divide ... is not political but philosophical; it's not Karl Marx vs. Adam Smith, it's Immanuel Kant's categorical imperative vs. William James' pragmatism. What the Germans really want is a clear set of principles: rules that specify the nature of truth, the basis of morality, when shops will be open, and what a Deutsche mark is worth. ... in an environment where deflation is more of a threat than inflation, an obsession with sound money can be a recipe for permanent recession. (Krugman 1999)

Robert Solow was also struck by the narrowness of the economic policy discussion in German expert circles when he contributed to a book on economic policy proposals for Germany and Europe:

All I want to do, as an outside observer, is to call attention to the extremely and unnecessarily narrow focus of the current discussion of macro-policy in expert circles in Germany. It is not too much to say, in my view, that there is almost no proper discussion of specifically macroeconomic problems and remedies. Instead, there is always talk of labor-market reform. ... These are important issues, and reforms are surely desirable. But stopping with them is exactly what I mean by a narrow focus and an evasion of macroeconomic factors. I think that this limitation is symptomatic of a misunderstanding of both the German situation and macroeconomic theory. (Solow 2008: 20)

The rest of this section will deal with one of the most spectacular examples of the narrowness of the German debate, the 'Hamburger Appell' ('Hamburg Appeal') in 2005 (Funke et al. 2005). In this appeal, more than 250 German university professors of economics ${ }^{1}-$ many of them prominent - collectively addressed the public in pre-election times in order to prevent German economic policy from taking demand-side measures and leaving its course of labour market deregulation, dismantling the welfare state and fiscal austerity that it had reinforced since 2003. After the launch of the appeal it became massively promoted by the 'Initiative Neue Soziale Marktwirtschaft' ('Initiative New Social Market Economy') sponsored by Gesamtmetall, the federation of German employers' associations in the metal and electrical engineering industries. Advertisements in leading German newspapers appeared referring to the Hamburg Appeal as ' 250 professors - 10 theses - one opinion'. The professors started their appeal with the following introduction:

The economic policy debate in Germany is increasingly being coined by conceptions that show an alarming lack of economic expertise. This is all the more reason for concern as Germany is in the midst of a deep structural crisis that calls for drastic and painful reforms. Precisely in pre-election times the willingness to bring this fact home to citizens with the necessary clarity will be small. Instead of that, important politicians yield to the temptation of propagating concepts that are not scientifically founded and aim at combining the agreeable with the useful: By adequate measures, it is suggested, an increase in domestic demand could be achieved, thereby leading to an overcoming of the structural growth crisis. This idea is wrong and dangerous. As academic teachers of economics we vividly caution against producing illusions thereby undermining the acceptance of necessary reforms. We appeal to the elected representatives' sense of responsibility to resist the temptation of easy solutions and

1. The complete list of signatories can be accessed via the following link: http://www.wiso.unihamburg.de/professuren/wachstum-und-konjunktur/hamburger-appell/unterzeichner/. 
to instead give non-sugarcoated answers to the pressing economic questions. (Funke et al. 2005: 1; translation by the author)

German professors were obviously very explicit in their rejection of any demand-side measures and in declaring them as a temptation they were even making it a moral issue to refrain from using them. Furthermore, in their view they were not just stating their opinion on the matter, but denounced other opinions as plainly wrong and not scientifically founded. Therefore, they invoked all their authority as scientists by referring to their status as academic teachers of economics. After the introduction they addressed 10 points on economic policy that in their view were important. In points 6 and 7 they specifically turned to fiscal policy issues:

The uncontrollably growing German government debt is quite correctly being perceived as future tax burden. ... Therefore, anybody who undermines the incentives to consolidate the government debt on the national or international level will damage the German interest. Any expansion of government debt will weaken domestic demand, because structural imbalances will be reinforced instead of cured, so that citizens and firms will have to act with increased caution. The (mass) purchasing power argument against 'saving oneself to death' in times of economic stagnation may be convenient, however, it is wrong. ... Therefore, responsible fiscal policy must be strictly stability-oriented. The consolidation of government finances calls for far-reaching cuts in all areas of public spending. ... Anybody claiming anything to the contrary will not do justice to the economic challenges for Germany or he will mislead citizens in a populist manner. (Funke et al. 2005: 2; translation by the author)

What is most remarkable in this quote - apart from the fact that German professors were, again, claiming to be in possession of the truth and were openly denouncing people with different opinions as potentially populist or undermining the German national interest is that it advocates far-reaching pro-cyclical budget cuts and claims that any increase in the government deficit will actually lead to a decrease in demand. The theoretical reasons given for this claim are few and weak. Indeed the theoretical foundation of the whole appeal is more than weak; it culminates in the brilliant insight that 'we need flexibility, readiness to innovate, entrepreneurial initiative and the courage for change' (Funke et al. 2005: 3; translation by the author). Apart from the long quote above, there is only one explicit theoretical argumentation against demand-side measures:

Additionally, all income ... unfolds demand effects; even savings always finance a debtor's demand. Intervention in favour of a particular form of demand will therefore primarily lead to shifting between consumption, investment and government demand. This disturbs the structure of overall demand but hardly leads to any increase in it. (Funke et al. 2005: 3; translation by the author)

However, this quote obviously only refers to the validity of Say's law and total crowding out in the standard neoclassical textbook model (see for example Felderer/Homburg 1992: 58 and 118-121) and it neither explains why expansionary fiscal policy should actually be detrimental to economic activity nor does it pay tribute to the many other, more Keynesian standard textbook models that find fiscal policy to be effective. Therefore, the only way to justify the German professors' claims is to involve non-Keynesian effects in general and in the particular German case in 2005. The mention of the perception of public debt as a future tax burden in the above quote is a clear hint in this direction. However, the case for the dominance of non-Keynesian effects is difficult to make - above all, when it is stated in such an apodictic way denying any other possibility as unscientific. Of course, non-Keynesian effects were intensely discussed at 
the time, but it can hardly be said that they were as uncontroversial as postulated by the German professors. By 2005, non-Keynesian effects had made their way into the standard macroeconomic textbooks. However, they were certainly not referred to as the normal or standard - let alone only - case, but as a theoretical possibility that may become important empirically under certain rather narrow conditions (see for example Blanchard 2003: 364). What is worse is that German professors were ignoring that there were at the time three empirical studies (Leibfritz et al. 2001; SVR 2003; Plötscher et al. 2005) that investigated the existence of non-Keynesian effects for Germany. All of them mention the possibility of NKE, but come to the conclusion that in the short run Keynesian effects dominate in Germany - a clear refutation of the German professors' assertion. The only way out of this embarrassing situation may be to deny that there were any demand-side problems in Germany at the time of the appeal in 2005, which of course is explicit in the frequent classification of the crisis as 'structural' by the professors. However, according to all existing estimates the output gap was substantially negative in 2005, which is a widely accepted standard indication that, indeed, there were demand-side problems and that in principle it would have been possible to increase production and to decrease unemployment by demandside measures without creating any inflationary pressures. In retrospect, the European Commission (2013) estimates the output gap for Germany in 2005 to be -2.1 per cent of GDP, which points to the second-largest negative demand-side disturbance in postunification Germany, the largest only having occurred in 2009 with -4.0 per cent.

Therefore, it must be concluded that the 250 professors - although invoking their authority as academic teachers and strongly denouncing other opinions as wrong and irresponsible - were in fact giving advice that was plainly in contradiction to both standard textbook knowledge and to the available empirical studies. If such a large and important fraction of a country's academic economists can publicly deviate from the most basic academic standards without any major critical discussion and objection within the scientific community, this will have to be termed a case of first-rate economic science failure.

\section{THE GERMAN DEBT BRAKE: GOOD LUCK RATHER THAN GOOD EXAMPLE}

With the intellectual background just described it does not come as a big surprise that in the summer of 2009 the German grand coalition government - supported almost unanimously by the stubbornly anti-Keynesian German economics community - decided with the necessary two-thirds majority in both houses of the German federal parliament to introduce a debt brake into the German constitution; and hence an instrument that will severely constrain the macroeconomic use of fiscal policy in the future.

The debt brake essentially comprises three elements. The structural component imposes strict limits on structural government deficits -0.35 per cent of GDP for the federal level (the Bund) and 0.0 per cent for the federal states (the Länder). The cyclical component increases or decreases these limits in accordance with the economy's cyclical position. An exception clause, finally, permits the limits to be transgressed in exceptional circumstances. Transitional periods for complying with the limits on structural deficits are written into the constitution: 2016 for the Bund and 2020 for the Länder. The legislation also provides for consolidation aid for five Länder under strict conditions regarding consolidation efforts. The German Debt Brake poses many problems also from an economic mainstream perspective. 
First, the capping of structural government net borrowing at 0.35 per cent of GDP for the Bund and the banning of all structural deficits by the Länder is completely arbitrary. It means that with an average annual growth in nominal GDP of 3 per cent, the national debt-to-GDP ratio will converge to just 11.7 per cent in the long run. There might be some mainstream arguments for some ceiling on the debt ratio, but - if anything - recent empirical research indicates that the critical threshold beyond which government debt might harm growth is above 80 or even 90 per cent. ${ }^{2}$ By imposing artificial limits on what has traditionally been the safest form for financial investment, the debt brake will instead deprive capital markets of a crucial stability anchor and a vital benchmark. It is unclear into which financial assets and to which countries the traditionally high excess savings and the accumulated financial wealth of the German private sector will be diverted in the future, but it will likely contribute to more unstable financial markets.

Second, by using a debt brake, Germany's fiscal policy is ignoring a broadly accepted economic yardstick for the scale of public deficits - the Golden Rule and thus turning its back on 60 years of theoretical common sense. The Golden Rule or the 'pay-as-you-use' principle as a growth-oriented rule for government deficits permits structural deficits beyond the cycle equivalent to net public investment. The rule involves several generations in financing public capital accumulation, since future generations will benefit in terms of greater prosperity from the productive investments made today (see Musgrave 1959). Giving up this rule decreases incentives for public investment in the standard logic as current generations have to pay for all of the investment but will receive only part of the future utility.

Third, the debt brake was introduced at a time when public budgets were markedly underfinanced in structural terms, as they have come under repeated strain from tax cuts for many years. Where governments are expected to balance their budgets in structural terms - or to come very close to doing so - on a given date without already having closed the revenue gap, their budget policy faces years of stringent pressure on spending. In macroeconomic terms, this is an extremely risky course of action with potentially negative impacts on growth and employment as adjustments are made, particularly against the backdrop of the precarious economic situation at the time of the introduction in 2009, but of course also at the time of writing in early 2013 . Furthermore, it will unquestionably go hand in hand with substantial cuts in the provision of public goods, services and welfare. If this then leads to the necessary public investment being scrapped or cut in future years, the much-vaunted principle of 'generational fairness' will be greatly damaged.

Fourth, the debt brake will ultimately have a pro-cyclical effect because of the way the commonly used cyclical adjustment method works and will, as a result, destabilise economic development. During times of downturn, too much consolidation will be required while, conversely, too little will be required during periods of recovery.

Fifth and finally, the impact of the debt brake is also, of course, critically dependent on its precise technical design and on how the underlying cyclical adjustment method and the applicable budget sensitivities are selected. Although the Bund has already opted for the

2. See for example Checherita/Rother (2010); Kumar/Woo (2010); Ostry et al. (2010); Reinhart/ Rogoff (2010); Caner et al. (2011); Cecchetti et al. (2011). However, as Nersisyan/Wray (2010) have convincingly demonstrated, such studies suffer from serious methodological shortcomings and should, therefore, not be taken as a guideline for economic policy. The doubts as to the original contribution by Reinhart and Rogoff have recently been reinforced strongly by the discovery by Herndon et al. (2013) of major unbelievable flaws in the underlying calculations. 
method used by the European Commission as part of its own monitoring of member states' budgets, the decision about the details of implementation is taken by the Ministries for Finance and Economics, so the mechanism is anything but transparent and is open to manipulation. As far as the Länder are concerned, for many of them detailed implementation is still an open question (see Deutsche Bundesbank 2011 and 2012).

Despite all these shortcomings and problems, the practical results might still seem impressive at first glance. The federal government has been claiming since 2011 that it is clearly over-fulfilling the debt brake's requirements for the federal budget (see FMF 2013). And with respect to the general government budget, the fiscal exit after the stimulus packages to counter the recession in 2009 and 2010 was quick and apparently smooth: the 2010 budget deficit of 4.1 per cent of GDP had been turned into a small surplus of 0.1 per cent of GDP within only 2 years by 2012. The structural budget balance, according to the European Commission's winter forecast, was already in surplus in 2012, amounting to 0.1 per cent of GDP. For 2013 and 2014 the forecast values are 0.4 per cent and 0.3 per cent of GDP respectively (European Commission 2013, p. 43). Finally, German government bonds were spared all the attacks on the financial markets, and the German government can finance itself at record low interest rates.

Therefore, it might seem logical to regard the German Debt Brake as a tried and tested instrument of a successful and sound fiscal policy and declare it a shining example and role model for the future of all European countries. The inclusion into the German constitution of stringent limits on sovereign debt, it is argued, enhances the country's credibility on the financial markets, leading to lower risk premiums and, hence, easier public sector financing (see Heinemann et al. 2011). This logic suggests, then, that exporting the German Debt Brake or similar fiscal rules to the euro area countries currently in crisis was a major contribution to solving the euro crisis. When most EU governments agreed to the fiscal compact in 2012 introducing stricter limits on public debts and deficits, where possible incorporating them into the Constitutions (European Council 2012), this resulted primarily from an acute sense of panic in the face of the continuing escalation of the euro crisis. For the first time, even the bonds of hitherto unaffected countries had come under pressure in the financial markets. But the fact that European governments resorted to the German approach of constitutionally fixed debt brakes certainly also has something to do with the allegedly easily demonstrable success of the German example.

However, praising the German debt brake as well as the agreement on the Fiscal Compact were both premature for a whole number of reasons. First of all, a considerable part of the successful consolidation up to now is based solely on the completely unexpected and rapid economic recovery in 2010 and 2011. In these 2 years, real GDP increased by 4.1 per cent and 3.0 per cent respectively and the unemployment rate fell in an impressive manner. Such conditions mean that budget consolidation is feasible and indeed easy because tax revenues increase and spending on unemployment benefits automatically decreases. This situation paradoxically also helps to reduce the 'structural' - that is, cyclically adjusted - deficit which should in principle be independent from the temporary ups and downs of the economy. As is the case with almost all cyclically adjusted procedures, the structural balance will not remain unaffected by the cyclical conditions of the economy since, by the very nature of the method of cyclical adjustment, potential output and structural budget balances are sensitive to variations in actual output.

In fact, it turns out that a substantial part of the structural consolidation success in the German budgets is based on 'presents' made by the endogeneity of the method. For example, from its Spring 2010 to its Autumn 2012 forecast the European Commission 
revised its forecast of actual real GDP for the year 2011 upwards by +4.1 percentage points. However, the estimated output gap increased only by 2.6 percentage points (European Commission 2010 and 2012). This means that the estimate of potential output was increased by 1.5 percentage points due to the unexpectedly strong upswing. Multiplying this number by the budget sensitivity of 0.51 for Germany gives a "present' in terms of structural consolidation of 0.75 percent of GDP. Furthermore, there is evidence that the budget sensitivity used - especially with respect to taxes is much too small. Own calculations with data from the German group of tax revenue forecasters show that from the Spring 2010 tax revenue forecast to the latest forecast, the general government tax revenue for 2011 was revised upwards by 59 billion euros (2.3 per cent of GDP) after controlling for changes in the tax code. The forecast for real GDP over the same period was raised by 3.8 percentage points. This implies a sensitivity of tax revenues to real GDP of 0.56; however, the European Commission as well as the German federal government uses a value of only 0.3 in its method of cyclical adjustment. Therefore, recent structural consolidation in Germany as it shows up in the federal budget or the EU Commissions estimates can be explained, to a large part, by endogenous technical revisions of potential GDP as a reaction to upward revisions of actual GDP and tax revenue. In a cyclical downturn, these consolidation successes would soon disappear (Truger/Will 2013: 177-183) and German fiscal policy might quickly get into trouble again.

In addition, if one assumes comparatively rational behaviour in the financial markets, the German debt brake should not be able to increase the government's credibility. The procedure practised by the federal government largely lacks transparency and is subject to cosmetic changes. The procedure for cyclical adjustments, which follows that of the European Commission, contains so many adjustable screws and possibilities for manipulation that the structural deficits can be calculated virtually at will. Thus on the basis of the general method employed by the federal government, Germany's structural deficit for 2010 could be anywhere between 10 billion and 40 billion euros (Truger/Will 2013: 165-169).

Worse still, the federal government, which has got into the habit of criticising other European governments for their allegedly dubious fiscal policies, has in its own practical implementation of the debt brake ensured a lack of transparency and has manipulated the situation (Truger/Will 2013: 169-172). The specific procedures used for the 2011 budget were not published in detail until after the budget had been passed. Finally, the federal government used a number of tricks (setting the basic structural deficit for 2010 too high, skilful timing of the switch to a new procedure for making cyclical adjustments) to weaken the requirements on the debt brake and thus enabled such a clear over-fulfilment of the requirements in the first place. How credibility and confidence are to be favoured in the international financial markets by such behaviour is difficult to imagine. In fact, taking a closer look at the movement of government bond yields over time shows that financial markets do not seem to be too impressed by the German debt brake (see Figure 1).

Whereas there have certainly been growing risk premiums for most of the euro area countries' government bond yields as compared to the German benchmark since the onset of the crisis, the same is true as compared to the government bond yields of many other countries, such as the US, the UK, Japan and Switzerland. The Swiss example is especially telling. As far back as 2003, the Swiss introduced a constitutional debt brake at the federal level. From 2003 to 2010, the Swiss public debt ratio fell by 15 percentage points - mainly because of favourable economic trends just as in the recent German case (see Truger/Will 2012: 15-20) - from around 55 per cent to 40 per cent 


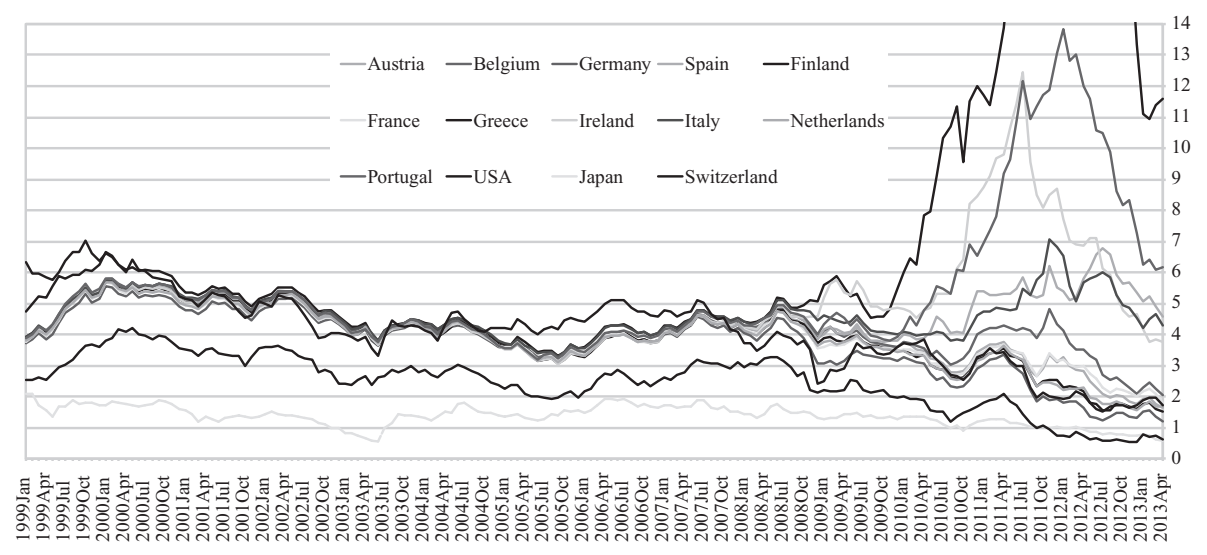

Source: ECB.

Figure 1 Ten-year government bond yields in percentages, selected euro area and other countries (1/1999-4/2013)

of GDP, whereas over the same period in Germany it rose by 20 percentage points from a good 60 per cent to over 80 per cent of GDP. However, the difference in yields between Swiss and German government bonds seems to have remained completely unaffected. Therefore, the whole premise of the European fiscal compact as a means to restore credibility and to reduce risk premiums on the financial markets must be seriously questioned.

It must be stressed, therefore, that the German debt brake is not a well-tested economic policy instrument at all. On the contrary, Germany and its debt brake are currently in the middle of a major fiscal policy experiment with a very uncertain outcome. The successes noted for the time being are mainly due to an unexpectedly strong and lasting economic recovery and the technically successful manipulation of figures by the federal government, whereas the real test under more severe economic conditions lies ahead.

\section{THE DEGREE OF AUSTERITY IMPLIED BY THE STABILITY AND GROWTH PACT AND THE FISCAL COMPACT}

Government deficits and debt in the EU are currently constrained by numerous rules. In their panic to calm down financial markets and prevent risk premiums for the crisis countries' government bonds from rising indefinitely, EU member states' governments kept on tightening the institutional constraints on public deficits and debt. Those constraints were certainly never simple in the past, but after the numerous hasty amendments they have become increasingly complex, so that it is quite difficult to disentangle which of the constraints will most probably become binding for the different member countries from 2013 onwards. Three sets of constraints at the European level seem to be most important in determining the fiscal stance in the euro area economies over the next 5 to 10 years.

First, there is the Excessive Deficit Procedure (EDP) with respect to budget deficits within the Stability and Growth Pact (SGP), which is currently being applied to all 
euro area members with the exception of Estonia, Finland, Germany, Luxembourg and Malta. It requires the general government budget deficit to be reduced to below 3 per cent of GDP. Member states under the EDP must bring their budget deficit below 3 per cent of GDP within a time period specified by the EU Council. For most countries the current deadline is 2013, although for Greece and Spain it is 2014 and for Ireland it is 2015 .

Second, there is the constraint for 'structural' (that is, cyclically adjusted and corrected for one-off measures) deficits under the Fiscal Compact. Member states that have not reached their medium-term budgetary objective had already been obliged to decrease structural deficits annually by a minimum of 0.5 per cent of GDP under the old SGP. The Fiscal Compact has made these prescriptions more binding by calling for institutionalised debt brakes on the national level that are to ensure that structural deficits are kept below 0.5 per cent of GDP. The compact has become effective in 2013 and calls for a fast transition to the new structural deficit targets with the exact deadlines still unclear and to be specified by the EU Council.

Third, the new debt-related branch of the EDP calls for a 1/20th annual reduction of the excess of the debt-GDP ratio over the 60 per cent threshold of the SGP. This rule will become effective after a short transition period after member states have left the EDP - that is, after they have reached the 3 per cent target with respect to the budget deficit. The consequences of this rule are the most difficult to assess, because they require many assumptions to be made. Given the initial debt-to-GDP ratio in order to project the future evolution of this ratio, information about the evolution of the primary government balance, the nominal interest rate and the nominal GDP growth rate are necessary. If all the deficit reductions necessary under the SGP and the fiscal compact were quickly implemented, nominal GDP growth were not too slow and the average interest rate on government bonds remained largely unchanged, then the major part of consolidation would already have been achieved by the earlier deficit reductions. For most of the member states, the additional negative fiscal stances required to meet the debt criterion would then be comparatively small. For the periphery countries, however, the necessary additional restraint could be considerable, due to the high debt level they will have reached when the debt criterion becomes binding.

In order to assess the resulting fiscal stance for the different euro area economies, different methods can be employed. One method is to retrospectively assess the annual changes in structural deficits by way of cyclically adjusting government balances. For projections of the necessary future fiscal stance one can then use the actual deficit in 2012 and the 2012 estimate of the structural balance and see which adjustment is necessary in order to meet the different criteria under the fiscal compact and then choose the most binding one under plausible assumptions for the necessary parameters (see Truger/Paetz 2012). However, as demonstrated in the German case in Section 3, using cyclically adjusted balances can be highly misleading, because of the endogeneity of potential output estimates. In the case of a severe recession or a long period of stagnation, potential output and also the structural budget balance will be adjusted downwards and consolidation efforts will be underestimated. It is therefore preferable to use data on actual discretionary consolidation efforts. ${ }^{3}$ In the present article we use data from the 2012 update of the OECD report 'Restoring public finances', which is based on OECD countries' governments' answers to a questionnaire sent out in order

3. This is also the conclusion recently drawn by Guajardo et al. (2011) in their reassessment of the evidence for expansionary consolidation. 


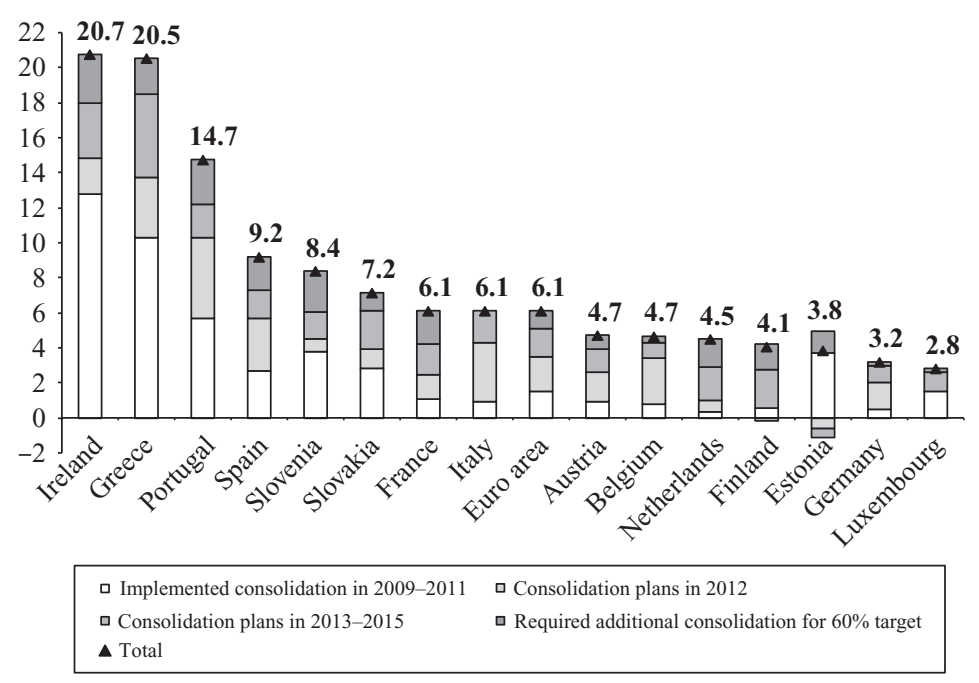

Source: OECD (2012); author's calculations.

Figure 2 Implemented, planned and additionally required consolidation measures for 60 per cent target in selected euro area countries as a percentage of GDP

to get information about the size and composition of OECD countries' consolidation efforts (OECD 2012). The study distinguishes between four groups of consolidation measures according to time. Measures that have already been implemented in 2009 to 2011, measures planned for 2012 to 2013, for 2014 to 2015 and additional measures that are required according to OECD calculations if the countries are to meet the 60 per cent debt limit by 2030 (Figure 2).

The already-implemented consolidation measures from 2009 to 2011 amount to 1.5 per cent of GDP for the euro area average, however with remarkable differences between countries: whereas Germany's consolidation efforts amounted to a moderate 0.5 per cent of GDP, the respective values in the periphery were very high -2.7 per cent in Spain, 5.7 per cent in Portugal, and, stunningly, 10.3 and even 12.8 per cent in Greece and Ireland respectively. As of 2012, consolidation efforts cumulate to 3.5 per cent of GDP for the euro area on average, and to between 4.3 per cent (Italy) and 14.8 per cent (Ireland) in the periphery. ${ }^{4}$ Taken together, implemented and planned consolidation measures from 2009 to 2015 cumulate to 5.1 per cent in the euro area on average, to between 6.1 per cent (Italy) and 18.5 per cent (Greece) of GDP. With more than 60 per cent on average over the countries, the consolidation measures clearly focus on the expenditure side. On top of that, the OECD estimates the additional consolidation requirements in order to meet the debt criterion of the SGP to be between 1.9 and 2.8 per cent of GDP in the periphery (with the exception of Italy). Germany's total consolidation effort, with 3 per cent of GDP, looks very small in comparison.

4. The OECD only gives cumulated values for consolidation efforts in 2012 and 2013. Therefore, the planned consolidation effort for 2012 was calculated using the individual country data provided in ch. 2 of OECD (2012). 


\section{THE ECONOMIC EFFECTS OF AUSTERITY: A THREE-STEP STRANGULATION OF THE EURO AREA ECONOMY IS IMMINENT}

The potential economic consequences of austerity in the huge dimension stated in the previous section can most easily be illustrated by using the concept of the fiscal multiplier. Multiplying the cumulative negative fiscal stance for a given year in relation to some base year with the multiplier gives a rough estimate of the output effects of austerity relative to a baseline scenario without any consolidation measures. The size of the multiplier then becomes the pivotal issue. Unfortunately, economic theory is rather inconclusive as to the size of the multiplier. On the one hand, traditional Keynesian approaches would assume high multipliers clearly above one, maybe even high enough for the paradox of thrift to occur, so that the attempt to reduce the budget deficit would in fact lead to a higher deficit due to the negative macroeconomic repercussions of fiscal consolidation. On the other hand, neoclassical economists, proponents of Ricardo/ Barro-equivalence in the tradition of Barro (1974) or supporters of the New Consensus Macroeconomics would assume a zero or at least very small multiplier. Finally, adherents of non-Keynesian effects in the tradition of Giavazzi/Pagano (1990) or Alesina/ Perotti (1995) - like the more than 250 German economists who signed the Hamburg appeal from Section 2 - would even believe in negative multipliers.

Maybe one of the very few and small positive side effects of the Great Recession and the austerity crises in many countries is that they have strongly encouraged empirical research on fiscal policy effectiveness and the size of the multiplier. And, in fact, many of the recent studies support the more Keynesian views of a sizeable multiplier. First, the case for expansionary consolidation has been severely damaged by Guajardo et al. (2011) and Perotti (2012). Second, especially under the current conditions in the euro area with monetary policy at the lower bound, fixed exchange rates within the currency union and simultaneous consolidation, the multiplier tends to be large and (sometimes well) above one (Batini et al. 2012; Baum et al. 2012; Coenen et al. 2012; De Long/Summers 2012; Holland/Portes 2012; Auerbach/Gorodnichenko 2013; Blanchard/Leigh 2013). Third, as suggested by the standard Keynesian textbook models and the Haavelmo Theorem, the expenditure multiplier tends to be larger than the revenue side multiplier (Batini et al. 2012; Gechert/Will 2012; Auerbach/Gorodnichenko 2013). Fourth, multipliers tend to be higher during strong recessions (Baum/Koester 2011; Creel et al. 2011; Batini et al. 2012; Baum et al. 2012; Fazzari et al. 2012; Auerbach/Gorodnichenko 2013). According to Batini et al. (2012: 23), the expenditure multiplier during recessions may be in the range of 1.6 to 2.6 , whereas the tax multiplier only in the range of 0.16 to 0.35 .

Of course, the recent studies are interesting in themselves, and may even constitute considerable progress from an econometric or methodological perspective. However, it should be noted that most of their conclusions - most notably that there tend to be sizeable multipliers and that expenditure multipliers are larger than revenue-side ones could easily also have been drawn on the basis of the earlier literature well before the crisis (see for example the overviews by Hemming et al. 2002; Arestis/Sawyer 2003; Bouthevillain et al. 2009; Creel et al 2011). Therefore, both politicians and their economic advisors could very well have known about the risks of austerity.

Applying multipliers of the order of magnitude in line with the older and more recent reviews of the literature to fiscal stances of the order of magnitude shown before unavoidably results in the devastating economic effects of austerity policies in the euro area. Even assuming a moderate multiplier of only 1 would lead one to conclude that, from 2009 to 2012, consolidation in the euro area has led to a GDP loss of 3.5 per cent 
Table 1 Real GDP growth rate and unemployment rate in the euro area countries, in percentages (2008-2014)

\begin{tabular}{|c|c|c|c|c|c|c|c|c|c|c|c|c|c|c|}
\hline & \multicolumn{7}{|c|}{ GDP growth } & \multicolumn{7}{|c|}{ Unemployment rate } \\
\hline & 2008 & 2009 & 2010 & 2011 & 2012 & 2013 & 2014 & 2008 & 2009 & 2010 & 2011 & 2012 & 2013 & 2014 \\
\hline Austria & 1.4 & -3.8 & 2.1 & 2.7 & 0.7 & 0.7 & 1.9 & 3.8 & 4.8 & 4.4 & 4.2 & 4.4 & 4.5 & 4.2 \\
\hline Belgium & 1.0 & -2.8 & 2.4 & 1.8 & -0.2 & 0.2 & 1.5 & 7.0 & 7.9 & 8.3 & 7.2 & 7.3 & 7.7 & 7.7 \\
\hline Cyprus & 3.6 & -1.9 & 1.3 & 0.5 & -2.3 & -3.5 & -1.3 & 3.7 & 5.4 & 6.3 & 7.9 & 11.9 & 15.5 & 16.9 \\
\hline Estonia & -4.2 & -14.1 & 3.3 & 8.3 & 3.2 & 3.0 & 4.0 & 5.5 & 13.8 & 16.9 & 12.5 & 10.0 & 9.8 & 9.0 \\
\hline Finland & 0.3 & -8.5 & 3.3 & 2.8 & -0.1 & 0.3 & 1.2 & 6.4 & 8.2 & 8.4 & 7.8 & 7.7 & 8.0 & 7.9 \\
\hline France & -0.1 & -3.1 & 1.7 & 1.7 & 0.0 & 0.1 & 1.2 & 7.8 & 9.5 & 9.7 & 9.6 & 10.3 & 10.7 & 11.0 \\
\hline Germany & 1.1 & -5.1 & 4.2 & 3.0 & 0.7 & 0.5 & 2.0 & 7.5 & 7.8 & 7.1 & 5.9 & 5.5 & 5.7 & 5.6 \\
\hline Greece & -0.2 & -3.1 & -4.9 & -7.1 & -6.4 & -4.4 & 0.6 & 7.7 & 9.5 & 12.6 & 17.7 & 24.7 & 27.0 & 25.7 \\
\hline Ireland & -2.1 & -5.5 & -0.8 & 1.4 & 0.7 & 1.1 & 2.2 & 6.4 & 12.0 & 13.9 & 14.7 & 14.8 & 14.6 & 14.1 \\
\hline Italy & -1.2 & -5.5 & 1.8 & 0.4 & -2.2 & -1.0 & 0.8 & 6.7 & 7.8 & 8.4 & 8.4 & 10.6 & 11.6 & 12.0 \\
\hline Luxembourg & 0.8 & -4.1 & 2.9 & 1.7 & 0.2 & 0.5 & 1.6 & 4.9 & 5.1 & 4.6 & 4.8 & 5.0 & 5.4 & 5.7 \\
\hline Malta & 3.9 & -2.6 & 2.9 & 1.7 & 1.0 & 1.5 & 2.0 & 6.0 & 6.9 & 6.9 & 6.5 & 6.5 & 6.4 & 6.2 \\
\hline Netherlands & 1.8 & -3.7 & 1.6 & 1.0 & -0.9 & -0.6 & 1.1 & 3.1 & 3.7 & 4.5 & 4.4 & 5.3 & 6.3 & 6.5 \\
\hline Portugal & 0.0 & -2.9 & 1.9 & -1.6 & -3.2 & -1.9 & 0.8 & 8.5 & 10.6 & 12.0 & 12.9 & 15.7 & 17.3 & 16.8 \\
\hline Slovakia & 3.6 & -8.0 & 1.4 & -0.2 & -2.0 & -2.0 & 0.7 & 9.6 & 12.1 & 14.5 & 13.6 & 14.0 & 14.0 & 13.6 \\
\hline Slovenia & 5.8 & -4.9 & 4.4 & 3.2 & 2.0 & 1.1 & 2.9 & 4.4 & 5.9 & 7.3 & 8.2 & 9.0 & 9.8 & 10.0 \\
\hline Spain & 0.9 & -3.7 & -0.3 & 0.4 & -1.4 & -1.4 & 0.8 & 11.3 & 18.0 & 20.1 & 21.7 & 25.0 & 26.9 & 26.6 \\
\hline Euro area & 0.4 & -4.4 & 2.0 & 1.4 & -0.6 & -0.3 & 1.4 & 7.6 & 9.6 & 10.1 & 10.2 & 11.4 & 12.2 & 12.1 \\
\hline
\end{tabular}

Note: 2013 and 2014: EU Commission forecasts.

Source: European Commission (2013)

compared to the unknown baseline without consolidation measures. In the periphery, the losses would then have been in the order of magnitude of 4.3 (Italy), 5.7 (Spain), 10.3 (Portugal), 13.7 (Greece) and 14.8 per cent (Ireland). The value for Ireland may of course be exaggerated as for such a small and extremely open economy the multiplier may actually be smaller.

In fact, a look at the development of GDP growth over time (see Table 1) shows that the countries with the largest negative fiscal stance are also those countries which are currently in recession. Although many other factors must be taken into account, it does seem pretty obvious that restrictive fiscal policy has prevented and/or ended the recovery in the most troubled economies and has driven them into recession, which in turn - together with the global economic slowdown - has been responsible for the stagnation in the rest of the euro area economies in 2012. Even before the recent slowdown, France (having started rather early with its 'fiscal exit') witnessed only a comparatively weak recovery. For Greece, Italy, Portugal and Spain the picture is pretty clear: their fall into recession coincides quite well with strong fiscal contraction.

What is worse is that consolidation did not come to an end in 2012 and that considerable further austerity is already planned or additionally implied by the debt-related criterion of the SGP. If applied under the assumption of a multiplier of 1, the fiscal constraints at work in the euro area will have the potential to weaken the (already weakened) euro area economic growth by a further cumulative 2.6 percentage points as compared to the unknown baseline. For most of the troubled economies in the periphery, the destructive potential is again much higher: over the medium term, Ireland, Greece, Spain, Italy 
and Portugal face the risk of losing a further 1.8 (Italy), 3.4 (Spain), 4.4 (Portugal), 5.9 (Ireland) and 6.8 (Greece) percentage points.

The negative output effects would of course also result in higher government deficits (and debt levels) as compared to the reference scenario which - under the current institutional and political circumstances - would in turn increase the necessary fiscal restriction in order to reach the given target values. This applies for all three fiscal constraints on the EU level: if the deadline to correct the excessive deficit under the currently active EDPs is not shifted, then further consolidation measures will become necessary with the result of a further economic deterioration. In the case of the fiscal compact, 'structural' deficits will also go up due to the endogeneity of potential output calculations, which in turn will increase the negative fiscal stance necessary for the fast reduction of the structural deficit to 0.5 per cent of GDP. And finally, higher deficits and lower GDP levels would lead to a rise in the debt-to-GDP level, which would lead to additional consolidation requirements under the relevant new branch of the EDP.

Therefore, the emergence of a vicious circle of consolidation efforts leading to higher deficits and debt levels and in turn to higher consolidation efforts and so on is a real and dangerous possibility in the current setting. And, in fact, in the case of Spain the potential vicious circle might already be under way: despite the fact that Spain was given more time to correct its excessive deficit, it still had to increase fiscal restriction to meet the new 'less ambitious' target as the economy was moving deeper into recession. The bad news is that this dangerous possibility can only be precluded by reforming all of the three relevant institutional constraints for fiscal policy at the same time. If the council decides to provide more leeway by shifting the EDP deadline, the necessary adjustment under the fiscal compact will automatically become larger. And if for some national or European reason the transition path to the almost balanced structural government balance is extended, then the adjustment required under the EDP-debt criterion will grow. What may look like a very tight three-layer system of ensuring fiscal 'sustainability' may in fact turn out to be the way towards a threestep or even triple strangulation of the euro area economy.

\section{CONCLUSIONS}

Economic policy in the euro area and Germany is in a sad state in at least two different respects. In the first sense, and most obviously, it is in a sad state because the current regime of strict austerity in the periphery countries, called for particularly by the German government, has produced devastating economic (and social) effects and will continue to do so under the current institutional setting. The output losses of the current strategy have been shown to be irresponsibly and unbearably high even under moderate assumptions regarding fiscal multipliers. In the second and more figurative sense, economic policy is in an even sadder state, because the devastating results were predictable and hence avoidable, had politicians and their economic advisors only cared to take standard macroeconomic textbook knowledge and readily available empirical results into account. Instead, the fact that the wrong decisions were taken can be traced back to a series of misunderstandings and misinterpretations that in turn were caused by an extremely narrow and biased view and an application of even the mainstream economic approaches and the empirical evidence: the German debt brake was mistakenly presented as a shining example and a remedy against growing mistrust on the financial markets. The German debt brake itself was introduced into the German constitution despite problems and flaws visible even from a more 
mainstream point of view. And a large number of German university professors who hailed the introduction of the debt brake could be shown to have publicly declared the dominance of non-Keynesian effects of fiscal policy as an unquestionable truth even though their claim was in clear opposition to standard textbook knowledge and the existing empirical studies.

\section{REFERENCES}

Alesina, A., Perotti, P. (1995): Reducing budget deficits, Columbia University Department of Economics, Discussion Paper Series No. 759.

Arestis, P., Sawyer, M. (2003): Reinventing fiscal policy, in: Journal of Post Keynesian Economics, 26(1), 3-25.

Auerbach, A.J., Gorodnichenko, Y. (2013): Fiscal multipliers in recession and expansion, in: Alesina, A., Giavazzi, F. (eds), Fiscal Policy after the Financial Crisis, Chicago: University of Chicago Press (forthcoming).

Barro, R.J. (1974): Are government bonds net wealth?, in: Journal of Political Economy, 42(6), 1095-1117.

Batini, N., Callegari, G., Melina, G. (2012): Successful austerity in the United States, Europe and Japan, IMF Working Paper, WP/12/190, Washington, DC.

Baum, A., Koester, G.B. (2011): The impact of fiscal policy on economic activity over the business cycle - evidence from a threshold VAR analysis, Deutsche Bundesbank Discussion Paper Series 1: Economic Studies, No. 03/2011, Frankfurt a.M.

Baum, A., Poplawski-Ribeiro, M., Weber, A. (2012): Fiscal multipliers and the state of the economy, IMF Working Paper WP/12/286, Washington, DC.

Blanchard, O. (2003): Macroeconomics, 3rd edn, Upper Saddle River, NJ: Prentice Hall.

Blanchard, O., Leigh, D. (2013): Growth forecast errors and fiscal multipliers, International Monetary Fund Working Paper No. 13/1, Washington, DC.

Bouthevillain, C., Caruana, J., Checherita, C., Cunha, J., Gordo, E., Haroutunian, S., Langenus, G., Hubic, A., Manzke, B., Pérez, J., Tommasino, P. (2009): Pros and cons of various fiscal measures to stimulate the economy, in: Banco de Espana Economic Bulletin, July 2009, 123-144.

Caner, M., Grennes, T., Koehler-Geib, F. (2011): Finding the tipping-point - when sovereign debt turns bad, World Bank Policy Research Paper 5391, Washington, DC.

Cecchetti, S.G., Mohanty, M.S., Zampolli, F. (2011): The real effects of debt, Bank of International Settlements Working Paper No. 352, Basel.

Checherita, C., Rother, P. (2010): The impact of high and growing debt on economic growth: an empirical investigation for the Euro Area, European Central Bank Working Paper No. 1237, Frankfurt a.M.

Coenen, C., Erceg, Christopher J., Freedman, Charles, Furceri, Davide, Kumhof, Michael, Lalonde, René, Laxton, Douglas, Lindé, Jesper, Mourougane, Annabelle, Muir, Dirk, Mursula, Susanna, de Resende, Carlos, Roberts, John, Roeger, Werner, Snudden, Stephen, Trabandt, Mathias, in't Veld, Jan (2012): Effects of fiscal stimulus in structural models, in: American Economic Journal: Macroeconomics, 4(1), 22-68.

Creel, J., Heyer, E., Plane, M. (2011): Petit précis de politique budgétaire par tous les temps: les multiplicateurs budgétaires au cours du cycle, in: Revue de l'OFCE, 116(1), 61-88.

DeLong, J.B., Summers, L.H. (2012): Fiscal policy in a depressed economy, in: Brooking Economic Papers, 44(1), 233-297.

Deutsche Bundesbank (2011): Die schuldenbremse in Deutschland - wesentliche inhalte und deren umsetzung, in: Monatsbericht der Deutschen Bundesbank, October, 15-40.

Deutsche Bundesbank (2012): Zur entwicklung der länderfinanzen in Deutschland seit dem Jahr 2005, in: Monatsbericht der Deutschen Bundesbank, October, 31-51.

European Commission (2010): European economic forecast - Spring 2010, European Economy 2, Brussels: European Commission. 
European Commission (2012): European economic forecast - Autumn 2012, European Economy 7, Brussels: European Commission.

European Commission (2013): European economic forecast, Winter 2013, European Economy 1/2013, Brussels: European Commission.

European Council (2012): Treaty on stability, coordination and governance in the Economic and Monetary Union, 2 March 2012, Brussels, European Council, URL: http://european-council. europa.eu/eurozone-governance/treaty-on-stability?lang=en).

Fazzari, S.M., Morley, J., Panovska, I. (2012): State dependent effects of fiscal policy, Australian School of Business Research Paper No. 2012 ECON 27.

Felderer, B., Homburg, S. (1992): Macroeconomics and New Macroeconomics, 2nd edn, Berlin: Springer.

FMF [Federal Ministry of Finance] (2013): Fiscal consolidation in 2012 exceeds debt brake requirements, press release, 15 January, Berlin, URL: http://www.bundesfinanzministerium.de/ Content/EN/Pressemitteilungen/2013/2013-01-15-fiscal-consolidation-in-2012-exceeds-debtbrake-requirements.html.

Funke, M., Lucke, B., Straubhaar, T. (2005): Hamburger Appell, URL: http://www.wiso.unihamburg.de/fileadmin/wiso_vwl_iwk/paper/appell.pdf.

Gechert, S., Will, H. (2012): Fiscal multipliers: a meta-regression analysis, Institut für Makroökonomie und Konjunkturforschung, Working Paper No. 97, Düsseldorf.

Giavazzi, F., Pagano, M. (1990): Can severe fiscal contractions be expansionary? Tales of two small European countries, in: Blanchard, O., Fisher, S. (eds), NBER Macroeconomics Annual 1990, Vol. 5, Cambridge, MA: MIT Press, 75-111.

Guajardo, J., Leigh, D., Pescatori, A. (2011): Expansionary austerity: new international evidence, International Monetary Fund, Working Paper WP/11/158, Washington, DC.

Hein, E., Truger, A. (2010): Financial crisis, global recession and macroeconomic policy reactions the case of Germany, in: Dullien, S., Hein, E., Truger, A., van Treeck, T. (eds), The World Economy in Crisis - The Return of Keynesianism?, Marburg: Metropolis, 191-220.

Heinemann, F., Moessinger, M.-D., Osterloh, S. (2011): Nationale fiskalregeln - ein instrument zur vorbeugung von vertrauenskrisen?, in: Federal Ministry of Finance Monthly Report, August: 2.

Hemming, R., Kell, M., Mahfouz, S. (2002): The effectiveness of fiscal policy in stimulating economic activity: a review of the literature, International Monetary Fund Working Paper No. 02/208, Washington, DC.

Herndon, T., Ash, M., Pollin, R. (2013): Does high public debt consistently stifle economic growth? A critique of Reinhart and Rogoff, PERI Working Paper No. 322, Amherst, MA: Political Economy Research Institute.

Holland, D., Portes, J. (2012): Self-defeating austerity?, in: National Institute Economic Review, No. 222 (October), F4-F10.

Krugman, P. (1999): Why Germany kant kompete, URL: http://web.mit.edu/krugman/www/ kompete.html.

Kumar, M.S., Woo, J. (2010): Public debt and growth, International Monetary Fund Working Paper No. 10/174, Washington, DC.

Leibfritz, W. et al. (2001): Finanzpolitik im spannungsfeld des europäischen stabilitäts- und wachstumspaktes. Zwischen gesamtwirtschaftlichen Erfordernissen und wirtschafts- und finanzpolitischem Handlungsbedarf, ifo-Beiträge zur Wirtschaftsforschung 5, München, ifo-Institut für Wirtschaftsforschung.

Musgrave, R.A. (1959): The Theory of Public Finance. A Study in Public Economy, New York: McGraw-Hill.

Nersisyan, Y., Wray, L.R. (2010): Does excessive sovereign debt really hurt growth? A critique of This Time Is Different, by Reinhart and Rogoff, The Levy Economics Institute of Bard College, Working Paper No. 603, Annandale-on-Hudson.

OECD (2012): Restoring public finances, 2012 Update, Paris.

Ostry, J.D., Ghosh, A.R., Kim, J.I., Qureshi, M.S. (2010): Fiscal space, International Monetary Fund, Staff Position Note 10/11, Washington, DC. 
174 European Journal of Economics and Economic Policies: Intervention, Vol. 10 No. 2

Perotti, R. (2012): The 'austerity myth': gain without pain?, Bank for International Settlements, Working Papers No. 362, Basel.

Plötscher, M., Seidel, T., Westermann, F. (2005): Fiskalpolitik in Deutschland: eine empirische analyse am beispiel des vorziehens der steuerreform, Kredit und Kapital, 38(1), 23-51.

Reinhart, C.M., Rogoff, K.S. (2010): Growth in a time of debt, National Bureau of Economic Research Working Paper 15639, Washington, DC.

Solow, R. (2008): Broadening the discussion of macroeconomic policy, in: Schettkat, R., Langkau, J. (eds), Economic Policy Proposals for Germany and Europe, Milton Park: Routledge, 20-28.

SVR [Sachverständigenrat zur Begutachtung der gesamtwirtschaftlichen Entwicklung] (2003): Jahresgutachten 2003/2004. Staatsfinanzen konsolidieren - Steuersystem reformieren, Wiesbaden: Statistisches Bundesamt.

Truger, A., Paetz, C. (2012): The Economic Effects of Austerity Policies in Europe: Some Backof-the-Envelope Calculations, Berlin School of Economics and Law, Berlin, 7 May, URL: http://www2.euromemorandum.eu/uploads/truger_paetz_fiscal_policy_in_the_euro_area.pdf.

Truger, A., Will, H. (2012): Eine finanzpolitik im interesse der nächsten generationen: schuldenbremse weiterentwickeln: konjunkturpolitische handlungsfähigkeit und öffentliche investitionen stärken, Institut für Makroökonomie und Konjunkturforschung, Study No. 24, Düsseldorf.

Truger, A., Will, H. (2013): The German 'debt brake': a shining example for European fiscal policy?, Revue de l'OFCE / Debates and Policies, The Euro Area in Crisis, 127, 155-188. 